\title{
Impact of Nutritional Intervention on Serum Level of Interferon Gamma and Insulin Resistance in Obese Women: Considerations during the COVID-19 Crisis
}

Hend A. Essa*, Salwa M. El Shebini, Maha I. A. Moaty, Nihad H. Ahmed, Magda S. Mohamed, Salwa Tawfic Tapozada

Department of Nutrition and Food Science, National Research Centre, Dokki, Giza, Egypt

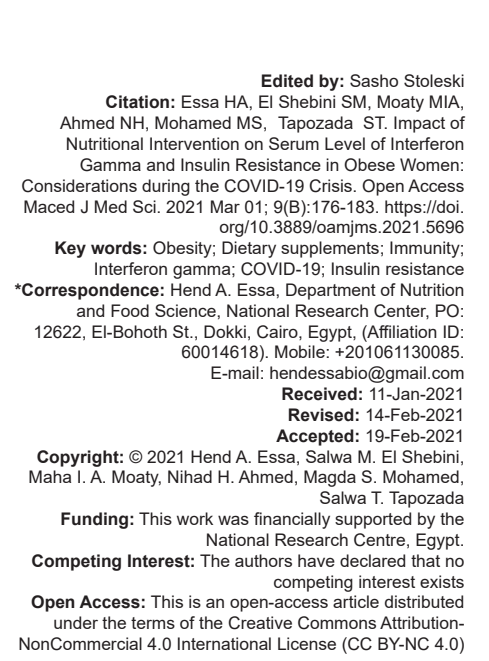

\section{Abstract}

BACKGROUND: Obesity represents a major epidemic worldwide; it is accompanied by increased oxidative stress and reduction in immune efficacy.

AIM: The objective was to assess the impact of a healthy balanced hypocaloric diet with two dietary supplements on obesity related metabolic disorders and interferon gamma production.

SUBJECTS AND METHODS: Sixty obese women participated in the study that lasted for 8 weeks. They were divided into two groups, 30 subjects in each group, one group consumed a daily supplement in the form of cookies prepared mainly from corn flour, wheat germ and thyme, and the other consumed a blend composed mainly of barley flour cocoa powder and ginger powder. All participants have followed a low caloric balanced regimen (1000-1200 KCal/ day). Follow-up was performed with anthropometric measurements, dietary recall, and biochemical parameters.

RESULTS: After intervention, the results showed a significant reduction in the anthropometric parameters, the obesity related metabolic disorders criteria with significant elevation in total antioxidant and interferon gamma. Positive significant correlations were detected between total antioxidant and interferon gamma and negative significant correlations were detected between interferon gamma with triglycerides, body mass index, percent body fat mass, and hip circumferences.

CONCLUSION: All these issues have a very important role in decreasing the infection with covid-19.

\section{Introduction}

Obesity has been tripled in the last 50 years around the world. Obese or overweight increased to be more than 1.9 billion adults in 2016 [1].

White adipose tissues are associated with metabolic complications, as insulin resistance, and generation of systemic oxidative stress and inflammation. Obesity predispose by in direct way for the risk of developing a number of diseases like cardiovascular disease, dyslipidemia, also increase the risk of pneumonia and acute respiratory distress syndrome [2].

Where, obesity is accompanied with reduction in the expression of angiotensinogen converting enzyme 2 (ACE2) in adipose tissues that have been linked with a numerous obesity-associated complication such as hypertension and renal failure [3].

Obesity is accompanied with reduction in immune efficacy and impairment in the activity of immune cells with reduction in interferon gamma and antibodies production [4] that mean increased susceptibility of obese individuals to viral and bacterial infection [5] and reduction in response to vaccination when compared to healthy weight individuals $[4,5]$.

Interferon gamma (INFy), is an important immune activator cytokine, where it has an important role in innate and adaptive immunity against viral and some bacterial infection. INFy has a critical role in the process of antibodies and antiviral immunity [6].

Whole wheat is widely consumed as edible grain in many countries worldwide, where wheat germ is an abundant natural source of antioxidants and antiinflammatory compounds like vitamin $E$, it is also a rich source of amino acids especially lysine, methionine, and threonine [7].

Maize is an important source of many bioactive compounds like carotenoids, where there is a negative correlation between the consumption of these phytochemicals and the risk of development of chronic diseases [8]. 
Barley is considered as a major food in some nations worldwide, it is also one of the richest sources in nutritional functional ingredients such as fiber, phenolic compounds, folate, and other anti-obesity, antioxidants, and anti-inflammatory bioactive compounds such as beta glucan [9].

Thyme or Avishane shirazi, is well known in many countries as a spice and a medicinal plant. Many studies demonstrated its antioxidant, anti-inflammatory, and antidiabetic capacity with its ability in enhancing immunity and insulin sensitivity [10]. Many studies demonstrated the beneficial effects of ginger and coca such as antiobesity and anti-inflammatory properties [11], [12].

Recently, it has been characterized by WHO that both COVID-19 outbreak and obesity (epidemic) as international community health crises. Global clinical and epidemiological observations confirmed that CO VID-19 can cause more severe symptoms and complications in people with obesity-related conditions. Indeed, Wu et al. [13] established the correlation between obesity-induced immune deficiency and COVID-19 adverse outcomes.

The aim of this study was to highlight the bad effects of obesity on immune function and to assess the impact of healthy balanced hypocaloric diet with two dietary supplements on obesity related metabolic disorders and interferon gamma production as an immune activator cytokine in immune function which could be associated with obesity.

\section{Subjects and Methods}

\section{Methods}

The first supplement (Corn cookies) was prepared from corn flour, wheat flour ( $72 \%$ extraction), and wheat germ, milk, corn oil, and thyme in a ratio presented in Table 1. All the ingredients were mixed with each other and kneaded with suitable amount of water and yeast were added and then left to ferment, then formed as cookies that were baked at $180^{\circ} \mathrm{C}$ for about 20 min [14]. The second supplement (Talbina) was prepared by mixing, barley flour with cocoa powder, ginger powder, and Arabic gum in a ratio presented in Table 1. The Talbina was cooked with water until it exhibited the suitable thickness.

Table 1: Formulas compositions

\begin{tabular}{lclc}
\hline Formula (1) & & Formula (2) & \\
\hline Ingredients & $\%$ & Ingredients & $\%$ \\
Corn flour & 40 & Barley flour & 70 \\
Wheat flour $(72 \%)$ & 30 & Milk & 20 \\
Wheat germ & 5 & Cocoa powder & 7 \\
Milk & 10 & Ginger powder & 2 \\
Corn oil & 10 & Arabic gum & 0.1 \\
Thyme & 3 & & \\
Yeast & 2 & & \\
\hline
\end{tabular}

\section{Chemical analysis}

Moisture, ash, crude protein, fat, and crude fiber contents were determined in samples (Pie and Talbina) according to the methods outlined in A.O.A.C. (2000) [14]. Carbohydrates were calculated by difference where carbohydrates $=100-(\%$ protein $+\%$ fat $+\%$ ash $+\%$ crude fiber) .

Total phenolic content, total flavonoids, and total antioxidant activity were determined in the two supplements according to Hagerman [15], Zhishen et al. [16], and Cheung et al. [17], respectively. Minerals contents ( $\mathrm{Fe}, \mathrm{K}$, $\mathrm{Na}, \mathrm{Ca}, \mathrm{Mg}$, and $\mathrm{Zn}$ ) in two supplements were determined according to the method described by (Takiyama and Ishii, 1992) [18]. Fatty acids and amino acids were determined using standard methods (AOCS, 1998; ljarotimi and Olopad, 2009) [19], [20].

\section{Subjects}

Sixty obese women participated as volunteers in this study that lasted for 8 weeks. They were divided into two groups, each group comprised 30 obese women, with mean age and mean body mass index (BMI) in the first and second group, respectively. All participants followed a low caloric balanced diet (1000$1200 \mathrm{Kcal} /$ day) for losing weight for 8 weeks. The protocol was approved by the "Ethical Committee" of the "National Research Centre (No. 19-180). In addition, an informed consent was obtained from each participant to be included in the study. This study started at the first of January and ended at the end of February 2020.

\section{Study Design and Interventions}

The first group consumed the corn cookies, two with breakfast and two with dinner (each weighed $20 \mathrm{~g}$ ), the second group consumed Talbina $30 \mathrm{~g}$ of the Talbina at breakfast and $15 \mathrm{~g}$ at dinner.

All the participants were examined at the beginning and at the end of the study with a weekly follow-up, for: Full medical history and medical examination, relevant anthropometric measurements (including height and weight using standard method [21]. Waist and hip circumferences in $\mathrm{cm}$, BMI was calculated as weight in relation to height (weight in $\mathrm{kg} /$ height 2 in meter), basal metabolic rate, and body fat mass was measured using Geratherm Body Fitness (B-5010), German.

\section{Dietary History}

Twenty-four hours dietary intake recall was recorded for all volunteers before and during the intervention. Nutrients intake was calculated before and during intervention using World Food Dietary Assessment System," (WFDAS), 1995, USA, University of California. 
Table 2: Chemical composition, total phenols, flavonoid, and antioxidant activity of the two dietary supplements (\% on dry weight basis)

\begin{tabular}{|c|c|c|c|c|c|c|c|}
\hline Samples & Protein & Fat & Ash & Fiber & Total phenols (mg GAE/g) & Total flavonoids ( $\mathrm{mg} \mathrm{CT/g}$ ) & Antioxidant activity (DPPH) (mg TE/g) \\
\hline Supplement 1 & 18.42 & 13.0 & 1.82 & 2.81 & 1.08 & 0.75 & 0.44 \\
\hline Supplement 2 & 15.79 & 7.09 & 2.04 & 2.21 & 0.90 & 0.66 & 0.32 \\
\hline
\end{tabular}

GAE: Garlic acid equivalent, CT: Catching equivalent TE: Trolox equivalent.

\section{Blood Samples and Biochemical Analysis}

Blood samples were obtained on the day of clinical examination after an overnight fast. The blood samples were allowed to clot, centrifuged and sera separated and divided into aliquots and stored in Eppendorf tubes at $-70^{\circ} \mathrm{C}$ until used for used for determination of the other biochemical parameters.

Fasting blood glucose (FBG) was determined on fresh sera using glucose oxidase method according to Trinder [22]. Serum total cholesterol was estimated according to Allain et al. [23], triglycerides was determined enzymatically according to Seidel et al. [24], and highdensity lipoprotein (HDL-C) was estimated according to Wornick et al. [25]. All lipid profile were estimated using the kit supplied by Erba Lachema s.r.o., Karásek 1d, 621 00 Brno, CZ. Low-density lipoprotein cholesterol (LDLC) was calculated according to the Friedewald et al. [26] equation and TGs/HDL-Ch ratio was calculated. Total antioxidant capacity as a marker of antioxidant capacity of the body was determined according to Koracevic et al. [27]. Fasting C-peptide level was measured by ELISA method (Monobind Inc. Lake Forest, CA 92630, USA). According to Bonser et al. [28], insulin resistance was expressed by modified homeostasis model assessment-insulin resistance according to Li et al. [29] $($ modified HOMA-IR $=1.5+$ FBG $(\mathrm{mg} / \mathrm{dl}) \times$ fasting C-peptide (nanograms per milliliter)/2800), quantitative determination of interferon gamma concentration was assessed according to Boehm et al. [30] by human IFN gamma ELISA kit supplied by Wuhan EIAab Science Co. Ltd., catalog number E0079h.

\section{Statistical Analysis}

This is a comparison between two groups of obese cases who consumed two different supplements. Furthermore, the reported data were compared within each group before and after the dietary intervention. All values were expressed as mean value \pm SE. Two-tailed student t-test was used to compare between data in the same group and between groups. Changes in different data were expressed as \% change from baseline. Correlation coefficient ( $r$ ) was calculated to find correlations between different variables. $p<0.05$ were considered statistically significant. Statistical analysis was performed using SPSS (10) software. SPSS window software version 17.0 (SPSS Inc. Chicago, IL, USA, 2008) was used.

\section{Results}

Tables 2-4 illustrated the percentage of protein, fat, and crude fiber of the two prepared supplements. The supplement (1) is higher in percentage of protein and fat while the supplement (2) is higher in the percentage of ash and fiber. The supplement (1) is a good source of protein with higher percentage in essential, alkaline, and branched chain amino acid. However, the supplement (1) as presented in table (2) is higher in total phenols, total flavonoids content, and antioxidants activity, also this supplement contains a higher amount of iron and potassium and low in sodium. The supplement (2) contains a higher amount in zinc, magnesium, and calcium. Although the supplement 1 is higher in fat content, the supplement 2 contains higher percentage of omega- 3 polyunsaturated fatty acids. The ratio between supplements 1,2 of $\omega-6 / \omega-3$ is $2: 1$ and 2.36:1 in two supplements, respectively. Table 3: Percent of amino acids and fatty acids in the two supplements

\begin{tabular}{lll}
\hline \% of amino acids & Supplement 1 & Supplement 2 \\
\hline Aspartic (ASP) & 0.60 & 0.43 \\
Threonine (THR) & 0.31 & 0.22 \\
Serine (SER) & 0.36 & 0.31 \\
Glutamic (GLU) & 1.97 & 2.27 \\
Glycine (GLY) & 0.37 & 0.29 \\
Alanine (ALA) & 0.37 & 0.31 \\
Valine (VAL) & 0.46 & 0.36 \\
Isoleucine (ILE) & 0.31 & 0.26 \\
Leucine (LEU) & 0.58 & 0.59 \\
Tyrosine (TYR) & 0.25 & 0.03 \\
Phenylalanine (PHE) & 0.45 & 0.38 \\
Histidine (HIS) & 0.19 & 0.25 \\
Lysine (LYS) & 0.33 & 0.20 \\
Arginine (ARG) & 0.44 & 0.27 \\
Proline (PRO) & 0.84 & 0.78 \\
Cysteine & 0.13 & 0.14 \\
Methionine & 0.10 & 0.09 \\
\% of fatty acids & & \\
Palmitic (16:0) & 11.22 & 13.03 \\
Linoleic (18:2, n-6) & 13.9 & 14.8 \\
Linolenic (18:3, n-3) & 27.9 & 34.89 \\
\hline
\end{tabular}

Table 5 demonstrated a comparison between the different macronutrients and the percent of the recommended dietary allowance (RDAs) of macronutrient intake of three types of dietary regimens daily consumed. The data showed the balanced and healthy distribution of the macronutrients in the two regimens compared to the habitual diet of the obese individuals.

Table 4: Levels of minerals $(\mathrm{mg} / 100 \mathrm{~g})$ in the two supplements

\begin{tabular}{lllllll}
\hline Samples & $\mathrm{Fe}$ & $\mathrm{K}$ & $\mathrm{Na}$ & $\mathrm{Ca}$ & $\mathrm{Mg}$ & $\mathrm{Zn}$ \\
\hline Corn pie & 65.63 & 455.96 & 88.44 & 213.63 & 119.20 & 27.25 \\
Talbina & 40.88 & 193.67 & 134.95 & 683.10 & 495.43 & 120.92 \\
\hline
\end{tabular}

\begin{tabular}{lllllll} 
Talbina & 40.88 & 193.67 & 134.95 & 683.10 & 495.43 & 120.92 \\
\hline
\end{tabular}

Table 6 showed the mean \pm SE of age, anthropometric measurements of the two groups at the start and the end of the study. All the anthropometric measurements of the two groups decreased significantly at $p<0.01$ by the end of the study. Comparing the 
percentage of changes between the two groups, the second group showed more percentage reduction of all anthropometric measurements.

Table 7 showed the mean \pm SE of the biochemical parameters of the two groups at the two the visits. The levels of all lipid parameters were significantly improved in two supplements groups, with more relevant to supplement (2), except for triglycerides in Group 1 showed nonsignificant reduction, also fasting blood glucose showed non-significantly reduction in both groups. The level of cystatin- $C$ showed a significant reduction in the mean concentrations of both groups. On the other hand, the concentrations of total antioxidant capacity and interferon gamma showed a significant reduction in the mean concentrations and nearly double reduction in \% change in Group 2 than Group 1. While, supplement 2 Group showed significant reduction in total antioxidant capacity and non-significant reduction in interferon gamma.

\section{Pearson Correlation between Interferon Gamma and Different Variables in the Two Groups at the Baseline of the Study}

\begin{tabular}{lll}
\hline Parameters & Cookies & Talbina \\
\hline Triglycerides & -0.046 & $-0.230^{* \star}$ \\
Total antioxidant capacity & $0.422^{* *}$ & $0.406^{\star *}$ \\
Modified HOMA & 0.037 & $0.213^{*}$ \\
Risk factor (triglycerides/high-density lipoprotein C) & -0.185 & $-0.194^{*}$ \\
Body mass index & $-0.482^{* *}$ & -0.210 \\
Fat mass & $-0.399^{*}$ & -0.202 \\
Waist circumference & -0.038 & -0.186 \\
Hip circumference & $-0.359^{* *}$ & -0.268 \\
\hline${ }^{*}$ (Numbers presented in this table are the value of $r=$ correlation coefficient), Correlation is significant at the \\
0.05 level (2-tailed).* ${ }^{\star *}$ Correlation is significant at the 0.01 level (2-tailed).
\end{tabular}

\section{Discussion}

In the present study, the obese participants were characterized by high BMI $>30 \mathrm{~kg} / \mathrm{m}^{2}$ and visceral adipose tissue expansion, which was indicated by an increased in fat mass, waist circumference, hip circumferences, and dyslipidemia. Other related complications like insulin resistance, with low grade inflammation demonstrated by a reduction in the serum level of total antioxidant capacity that might be due to a reduction in the expression of antioxidant enzymes along with excessive generation of free radicals and inflammatory cytokines in adipose tissues [31].

In obese subjects', adipose tissue macrophages deviate toward M1 phenotype and secretion of inflammatory cytokines such as tumor necrosis factor which contribute to insulin resistance [32]

Improving body weight and its related metabolic syndrome can be obtained by healthy balanced diet, physical activity along with supplements by dietary functional foods that have a role in improving obesity and other diseases [33], where foods, plants, and herbal medicine contain a huge amount of natural phytochemicals and other bioactive components that have a positive role on many diseases without any side effects like medications [33]. In this context, the aim of this study was assessing the efficiency of two dietary supplements on obesity and obesity related metabolic disorders and interferon gamma production as an important immune activator cytokine in immune function.

The analytical data of this study showed that the two dietary supplements, cookies and Talbina, are enriched with anti-obesity elements and immune enhancer active compounds such as fiber, essential amino acids, phenolic compounds, Vitamins, and minerals.

Corn, wheat germ, and barley have a considerable amount of dietary fiber in which have role in regulating body weight, by increasing satiety. However, the fiber helps in modulating intestinal microbial populations by increasing in the production in of short chain fatty acids in large intestine along with reducing the level of cholesterol and promoting its fecal excretion [34].

Our results are in agreement with Jin et al. [35], who stated that Beta glucan of corn and parley have a beneficial effect on the improvement of the levels of blood cholesterol, HDL-C, and glucose with increasing in satiety feeling.

Table 5: Daily intake of calories, macronutrient (as a \% of calories), mean values, and \% of the RDAs of macronutrient intake of three types of dietary regimens consumed by the obese volunteers

\begin{tabular}{|c|c|c|c|c|c|}
\hline Macronutrients intake & Habitual diet & Regimen with formula1 & Regimen with formula 2 & RDAs & $p$-value \\
\hline \multicolumn{6}{|l|}{ Mean \pm SE and $\%$ of the RDAs } \\
\hline Energy (kcal) & $\begin{array}{l}2459.33 \pm 33.92 \\
111.79\end{array}$ & $\begin{array}{l}1038.28 \pm 23.10 \\
47.19\end{array}$ & $\begin{array}{l}1035.47 \pm 20.48 \\
46.61\end{array}$ & 2200 & $0.000^{\star \star}$ \\
\hline Protein (g) & $\begin{array}{l}41.37 \pm 4.26 \\
82.74\end{array}$ & $\begin{array}{l}50.12 \pm 5.08 \\
100.04\end{array}$ & $\begin{array}{l}48.97 \pm 4.12 \\
97.94\end{array}$ & 50 & $0.000^{* *}$ \\
\hline Fiber (g) & $\begin{array}{l}14.55 \pm 0.53 \\
58.2\end{array}$ & $\begin{array}{l}23.09 \pm 0.21 \\
92.36\end{array}$ & $\begin{array}{l}24.15 \pm 0.12 \\
96.6\end{array}$ & 25 & $0.002^{*}$ \\
\hline Total carbohydrate $(\mathrm{g})$ & $\begin{array}{l}325.85 \pm 5.35 \\
108.62\end{array}$ & $\begin{array}{l}102.40 \pm 3.71 \\
34.13\end{array}$ & $\begin{array}{l}109.39 \pm 4.16 \\
36.46\end{array}$ & 300 & $0.000^{* *}$ \\
\hline Fat (g) & $\begin{array}{l}110.05 \pm 9.08 \\
142.92\end{array}$ & $\begin{array}{l}47.58 \pm 4.33 \\
61.79\end{array}$ & $\begin{array}{l}44.67 \pm 3.28 \\
58.01\end{array}$ & 77 & $0.000^{* *}$ \\
\hline Saturated fatty acids (g) & $\begin{array}{l}66.31 \pm 4.10 \\
24.16\end{array}$ & $\begin{array}{l}8.06 \pm 1.42 \\
6.99\end{array}$ & $\begin{array}{l}8.01 \pm 3.71 \\
6.96\end{array}$ & No more than $7 \%$ & $0.000^{* *}$ \\
\hline Monounsaturated fatty acids (g) & $\begin{array}{l}18.14 \pm 2.03 \\
6.59\end{array}$ & $\begin{array}{l}16.59 \pm 2.14 \\
14.38\end{array}$ & $\begin{array}{l}16.96 \pm 3.02 \\
14.74\end{array}$ & $12 \%-14 \%$ of total Calories & $0.010^{*}$ \\
\hline Polyunsaturated fatty acids (g) & $\begin{array}{l}15.23 \pm 1.40 \\
5.49\end{array}$ & $\begin{array}{l}9.67 \pm 2.46 \\
8.38\end{array}$ & $\begin{array}{l}9.74 \pm 2.11 \\
8.47\end{array}$ & $6-8 \%$ of total Calories & $0.012^{*}$ \\
\hline Cholesterol (mg) & $\begin{array}{l}386.97 \pm 13.25 \\
128.99\end{array}$ & $\begin{array}{l}188.31 \pm 7.49 \\
62.77\end{array}$ & $185.44 \pm 6.55$ & 300 & $0.000^{* *}$ \\
\hline
\end{tabular}


Table 6: Mean \pm SE of age and anthropometric parameters of obese women at the baseline and after the dietary intervention

\begin{tabular}{|c|c|c|c|c|c|c|}
\hline \multirow[t]{2}{*}{ Parameters } & \multicolumn{3}{|c|}{$\begin{array}{l}1^{\text {st }} \text { Group (Cookies) } \\
\text { (Consuming supplement } 1 \text { ) } \\
\text { (no.=30) }\end{array}$} & \multicolumn{3}{|c|}{$\begin{array}{l}2^{\text {nd }} \text { Group (Talbina) } \\
\text { (Consuming supplement } 2 \text { ) } \\
\text { (no.=30) }\end{array}$} \\
\hline & Baseline & After Intervention & $\%$ Change & Baseline & After intervention & $\%$ Change \\
\hline Age (year) & $43.62 \pm 1.01$ & & & $46.70 \pm 2.12$ & & \\
\hline Height $(\mathrm{cm})$ & $161.25 \pm 0.94$ & & & $154.87 \pm 0.88$ & & \\
\hline Body mass index $\left(\mathrm{kg} / \mathrm{m}^{2}\right)$ & $36.54 \pm 0.59$ & $35.49 \pm 1.01^{\star *}$ & -2.97 & $38.67 \pm 1.49$ & $36.72 \pm 1.04^{\star *}$ & -5.18 \\
\hline Body fat mass $(\mathrm{kg})$ & $42.13 \pm 1.96$ & $40.20 \pm 1.88^{\star \star}$ & -2.67 & $44.32 \pm 1.89$ & $41.03 \pm 1.60^{\star *}$ & -2.67 \\
\hline Waist circumference $(\mathrm{cm})$ & $91.18 \pm 1.49$ & $87.63 \pm 1.29^{* *}$ & -3.89 & $94.10 \pm 2.81$ & $87.60 \pm 2.37^{* \star}$ & -6.91 \\
\hline Hip circumference $(\mathrm{cm})$ & $118.39 \pm 1.88$ & $115.11 \pm 1.74^{\star \star}$ & -2.77 & $121.30 \pm 2.33$ & $116.85 \pm 2.42^{\star *}$ & -3.67 \\
\hline Basal metabolic rate (kcal) & $2134.47 \pm 36.11$ & $2078.89 \pm 23.54^{* *}$ & -2.61 & $2146.50 \pm 36.53$ & $2071 \pm 37.42^{\star}$ & -3.5 \\
\hline
\end{tabular}

Table 7: Mean \pm SE of the obesity-related metabolic disorders, total antioxidant capacity, and interferon gamma of obese women at the baseline and the end of the study

\begin{tabular}{|c|c|c|c|c|c|c|}
\hline \multirow[t]{2}{*}{ Parameters } & \multicolumn{3}{|c|}{$\begin{array}{l}1^{\text {st }} \text { Group (Cookies) } \\
\text { (Consuming supplement } 1 \text { ) } \\
\text { (no.=30) }\end{array}$} & \multicolumn{3}{|c|}{$\begin{array}{l}2^{\text {nd }} \text { Group (Talbina) } \\
\text { (Consuming supplement } 1 \text { ) } \\
\text { (no.=30) }\end{array}$} \\
\hline & Baseline & After intervention & $\%$ Change & Baseline & After Intervention & $\%$ Change \\
\hline FBG $(\mathrm{mg} / \mathrm{dl})$ & $116.66 \pm 7.8$ & $111.72 \pm 4.70$ & -4.24 & $107.81 \pm 3.60$ & $107.72 \pm 3.05$ & 0.08 \\
\hline Cholesterol (mg/dl) & $204.80 \pm 7.36$ & $186.09 \pm 6.31^{\star *}$ & -9.14 & $231.89 \pm 7.19$ & $213.07 \pm 5.25^{\star \star}$ & -8.11 \\
\hline Triglycerides (mg/dl) & $135.78 \pm 2.22$ & $133.76 \pm 2.21$ & -1.48 & $150.62 \pm 4.03$ & $142.23 \pm 3.56^{\star \star}$ & -2.25 \\
\hline High-density lipoprotein cholesterol (mg/dl) & $31.86 \pm 1.00$ & $37.04 \pm 1.01^{* *}$ & 16.26 & $32.13 \pm 1.17$ & $39.17 \pm 0.86^{* *}$ & 21.91 \\
\hline Low-density lipoprotein cholesterol (mg/dl) & $145.79 \pm 6.79$ & $122.30 \pm 6.20^{\star *}$ & -16.12 & $169.64 \pm 6.51$ & $145.45 \pm 4.9^{* *}$ & -14.25 \\
\hline $\begin{array}{l}\text { Risk factor (triglycerides/high-density } \\
\text { lipoprotein cholesterol) }\end{array}$ & $4.39 \pm 0.15$ & $3.69 \pm 0.12^{\star \star}$ & -21.50 & $5.11 \pm 0.32$ & $3.69 \pm 0.13^{\star \star}$ & -29.76 \\
\hline C-Peptide $\mathrm{ng} / \mathrm{ml}$ & $5.93 \pm 0.24$ & $5.25 \pm 0.23^{* *}$ & -11.47 & $6.05 \pm 0.19$ & $5.38 \pm 0.15^{\star \star}$ & -11.07 \\
\hline Modified HOMA-IR & $0.28 \pm 0.03$ & $0.23 \pm 0.02^{\star \star}$ & -17.85 & $0.25 \pm 0.013$ & $0.22 \pm 0.011^{* *}$ & -12 \\
\hline Total antioxidant capacity $\mathrm{mg} / \mathrm{dl}$ & $1.03 \pm 0.026$ & $1.11 \pm 0.027^{\star \star}$ & +7.21 & $0.810 \pm 0.023$ & $0.93 \pm 0.035^{\star \star}$ & +14.81 \\
\hline Interferon Gamma pg/ml & $165.69 \pm 3.28$ & $174.09 \pm 4.97$ & +5.48 & $173.77 \pm 7.88$ & $189.41 \pm 8.45^{\star \star}$ & +9.00 \\
\hline
\end{tabular}

In addition, several studies demonstrated the regulatory effects of beta glucan on immune response [36], [37], a clinical study showed their ability in the protection against infection and improvement of the immunogenicity of vaccines [38]. Our results are in agreement with Aoe et al. [39], who showed that beta glucan could decrease visceral obesity.

Redan et al. [40] declared that dietary supplements rich in phenolic compounds possess a safe inexpensive health therapeutic approach. On the other hand, Vernarelli and Lambert [41] established the anti-obesity effects of polyphenols rich diet, where high phenolic and flavonoids compounds improved BMI and anthropometric measurements such as waist and hip circumferences, also improved dyslipidemia, hypertension, and inflammatory status in addition to their huge power of antioxidant capacity. Another study by Shahidi and Ambigaipalan [42] showed the ability of polyphenols and their natural sources in modulating the immune response.

Tzounis et al. [43] reported that consumption of food containing cocoa flavanol increases the amount of Lactobacilli and Bifidobacteria in humans, which have a protective effect on immune response as they were enhancing the differentiation of the regulatory $T$ cells (Tregs) that produce anti-inflammatory cytokines.

The alterations in the metabolic environment associated with obesity can lead to loss of immune efficacy and impairment in the immune cells activity such as CD4+, CD8+, and B cells with reduction in antibodies and interferon gamma production [4] which explain why obese individuals are increase susceptibility to viral and bacterial infections as compared to healthy weight individuals [5].
The IFN- $\gamma$, considered as the central effector of cell mediated immunity, can manage a plenty of antimicrobial functions. It has a role in antigen presentation through antigen presenting cells by promoting antigen recognition through cognate $\mathrm{T}$-cell interaction, increases the production of reactive oxygen species induce antiviral responses [44].

Sheridan et al. [45] clarified the response of obese individuals and their immune systems, where the exposure of blood immune cells of obese, overweight, and healthy weight individuals to vaccine increased the number of IFN-production and CD8+ $(65 \%)$ in healthy weight individuals followed by overweight (60\%) and lastly obese individuals (40\%). This is what was shown with the COVID 19 epidemic, where the seriousness of infection was found among obese individuals.

In this line, a report from France established that $85.7 \%$ of severe acute respiratory syndrome coronavirus 2 (SARS-CoV-2) infected obese subjects required mechanical ventilation when compared to $47.1 \%$ of infected healthy weight subjects [46].

Recent evidence indicates that CoVs have evolved to influence the features of the human IFN pathway to enhance their pathogenesis [47]. Analyses of single-cell RNA sequencing data showed that tissues that would potentially harbors SARS-CoV-2, in human airway epithelial cells, IFN-I, and to some extent IFN II, upregulate ACE2 expression [48]. Angiotensin-converting enzyme, a key component of the renin-angiotensin system cleaves angiotensin I to generate angiotensin II, whereas ACE2 inactivates angiotensin II and is a negative regulator of the system. The actions of angiotensin II drive acute lung injury through various mechanisms, including increased vascular permeability [49]. 
Ahealthy, balanced diet with dietarysupplements that can offer the necessary macro- and micronutrients, prebiotics, restore, and maintain immune cell function, our two dietary supplements contain a considerable amount of micro-immunoenhancer compounds such as essential amino acids and fatty acids (like omega 3 ) with vitamins (like A,E, D, C) and minerals (like Zn, mg).

Besides, the potent anti-inflammatory effect omega- 3 fatty acids especially in the chronic state of inflammation like that found in obese individuals, it has an impact in modulating both innate, adaptive immunity which promotes $B$ cells activation [50].

Fan et al. [51] documented that branched chain amino acids have a role in the regulation of immune functions, through increasing fuel sources for innate and adaptive immune response and pro-inflammatory cytokines.

Zinc is an important cofactor for many enzymes, where magnesium and zinc have a control role on immune function. Hasan et al. [52] stated that zinc deficiency could be accompanied by a reduction in INF gamma and antibodies production 116 .

In accordance to vitamins such as C, E, and D that have a many role in several aspects of immunity, where they have a protective effects on influenza infection and in animal modules which was associated with improvement in Th1 responses as indicated by INF gamma and interleukin 2 production [53].

\section{Conclusion}

The reduction in the weight gain has several benefits toward improving many metabolic disorders associated with obesity such as dyslipidemia, insulin resistance, and inflammatory-immuno-disturbance. This study demonstrated that the dietary therapy with the two dietary functional foods supplemented rich in omega 3 , vitamins, and minerals with a hypocaloric diet improved the metabolic disorders associated with obesity, also increased the total antioxidant capacity with improving the level of interferon gamma. All these issues have a very important role in decreasing the infection with covid- 19 .

\section{Ethical Approval}

The research was given ethical approval from Ethical Committee of National.

Research Centre, (registration number is 19-180) and signed written informed consent was obtained from all subjects before enrollment.

\section{Authors' Contributions}

HE and SS designed research, SS was responsible for clinical examination, MManthropometrics measurements, HE had responsibility for biochemical analysis and laboratory investigations, HE wrote the manuscript, $\mathrm{NH}$ was responsible for preparation of the supplements and analysis of nutritional intake and dietary habit, HE and MM were responsible for statistical analysis. SS and ST were involved in consent signature by the subjects, have primary responsibility for final content. MS, had the responsibility for chemical analysis of the supplement;

All authors read and approved the final manuscript before submission.

All coauthors have reviewed and approved of the manuscript before submission.

\section{References}

1. World Health Organization, Obesity and Overweight; 2018 Available from: https://www.who.int/newsroom/fact-sheets/ detail/obesity-and-overweight. [Last accessed on 2020 Apr 05].

2. Trayhurn P, Wood IS. Adipokines: Inflammation and the pleiotropic role of white adipose tissue. Br J Nutr. 2004;92(3):34755. https://doi.org/10.1079/bjn20041213

PMid:15469638

3. Patel VB, Basu R, Oudit GY. ACE2/Ang 1-7 axis: A critical regulator of epicardial adipose tissue inflammation and cardiac dysfunction in obesity. Adipocyte. 2016;5(3):306-11. https://doi. org/10.1080/21623945.2015.1131881

PMid:27617176

4. Honce R, Schultz-Cherry S. Impact of obesity on influenza A virus pathogenesis, immune response, and evolution. Front Immunol. 2019;10:1071. https://doi.org/10.3389/fimmu.2019.01071 PMid:31134099

5. Frasca D, Blomberg BB. The impact of obesity and metabolic syndrome on vaccination success. In: Vaccines for Older Adults: Current Practices and Future Opportunities. Germany: Karger Publishers; 2020. p. 86-97. https://doi.org/10.1159/000504440

6. Ivashkiv LB. IFN $\gamma$ : Signalling, epigenetics and roles in immunity, metabolism, disease and cancer immunotherapy. Nat Rev Immunol. 2018;18(9):545-58. https://doi.org/10.1038/ s41577-018-0029-z

PMid:29921905

7. Meriles SP, Steffolani ME, León AE, Penci MC, Ribotta PD. Physico-chemical characterization of protein fraction from stabilized wheat germ. Food Sci Biotechnol. 2019;28(5):132735. https://doi.org/10.1007/s10068-019-00594-9

PMid:31695931

8. Shah TR, Prasad K, Kumar P. Maize-A potential source of human nutrition and health: A review. Cogent Food Agric. 2016;2(1):1166995.

9. Zeng Y, Yang J, Yang X, Pu X, Du J, Li X, et al. Nature's Contributions to Crop Diet in Environmental Extremes for Human Cognition; 2020.

10. Mahmoodi M, Koohpeyma F, Saki F, Maleksabet A. The 
protective effect of Zataria multiflora Boiss. Hydroalcoholic extract on TNF- $\alpha$ production, oxidative stress, and insulin level in streptozotocin-induced diabetic rats. Avicenna J Phytomed. 2019;9(1):72.

PMid:30788280

11. Dugasani S, Pichika MR, Nadarajah VD, Balijepalli MK, Tandra S, Korlakunta JN. Comparative antioxidant and antiinflammatory effects of [6]-gingerol, [8]-gingerol, [10]-gingerol and [6]-shogaol. J Ethnopharmacol. 2010;127(2):515-20. https://doi.org/10.1016/j.jep.2009.10.004

PMid:19833188

12. Andújar I, Recio M, Giner R, Ríos J. Cocoa polyphenols and their potential benefits for human health. Oxid Med Cell Longev. 2012;2012:906252. https://doi.org/10.1155/2012/906252

13. Wu C, Chen X, Cai $\mathrm{Y}$, Zhou $\mathrm{X}, \mathrm{Xu} \mathrm{S}$, Huang $\mathrm{H}$, et al. Risk factors associated with acute respiratory distress syndrome and death in patients with Coronavirus disease 2019 pneumonia in Wuhan, China. JAMA Intern Med. 2020;180(7):934-43. https:// doi.org/10.1001/jamainternmed.2020.0994

PMid:32167524

14. American Association of Cereal Chemists. Approved Methods of Analysis. $10^{\text {th }}$ ed. St. Paul, MN, USA: American Association of Cereal Chemists; 2000. p. 1200. https://doi.org/10.1016/ s0144-8617(01)00358-7

15. Hagerman A. Quantification of Tannins in Tree Foliage: A Laboratory Manual for the FAO/IAEA Co-Ordinated Research Project On, the Use of Nuclear and Related Techniques to Develop Simple Tannin Assays for Predicting and Improving the Safety and Efficiency of Feeding Ruminants on Tanninferous Tree Foliage; 2000.

16. Zhishen J, Mengcheng T, Jianming W. The determination of flavonoid contents in mulberry and their scavenging effects on superoxide radicals. Food Chem. 1999;64(4):555-9. https://doi. org/10.1016/s0308-8146(98)00102-2

17. Cheung L, Cheung PC, Ooi VE. Antioxidant activity and total phenolics of edible mushroom extracts. Food Chem. 2003;81(2):249-55. https://doi.org/10.1016/ s0308-8146(02)00419-3

18. Takiyama K, Ishii Y. Comparison of digestion methods for atomic absorption analysis of food materials. Anal Sci. 1992;8(3):41921. https://doi.org/10.2116/analsci.8.419

19. American Oil Chemists' Society. Methods and Recommended Practices of the American Oil Chemists' Society. Champaign, IL, USA: American Oil Chemists' Society; 1998. https://doi. org/10.1007/bf02671212

20. Ijarotimi O, Olopade A. Determination of amino acid content and protein quality of complementary food produced from locally available food materials in Ondo state, Nigeria. Malays $\mathrm{J}$ Nutr. 2009;15(1):87-95. PMid:22691808

21. Jelliffe D. The Assessment of the Nutritional Status of the Community. WHO Monograph Series No. 53. Geneva: World Health Organization; 1966. p. 50-69.

22. Trinder P. Determination of glucose in blood using glucose oxidase with an alternative oxygen acceptor. Ann Clin Biochem. 1969;6(1):24-7. https://doi.org/10.1177/000456326900600108

23. Allain CC, Poon LS, Chan CS, Richmond W, Fu PC Enzymatic determination of total serum cholesterol. Clin Chem. 1974;20(4):470-5. https://doi.org/10.1093/clinchem/20.4.470 PMid:4818200

24. Seidel J, Klos S, Ziegenhorn T. AACC meeting abstract 34. Clin Chem. 1993;39:1127.

25. Wornick DF, Albers JJ. A comprehensive evaluation of the heparin-manganese precipitation procedure for estimating high density lipoprotein cholesterol. J Lipid Res. 1978;19(1):65-76. https://doi.org/10.1016/s0022-2275(20)41577-9

\section{PMid:202660}

26. Friedewald WI, Levy RI, Fredrickson DS. Estimation of the concentration of low-density lipoprotein cholesterol in plasma, without use of preparative ultracentrifuge. Clin Chem. 1972;18(6):499-502. https://doi.org/10.1093/clinchem/18.6.499 PMid:4337382

27. Koracevic D, Koracevic G, Djordjevic V, Andrejevic S, Cosic V. Method for the measurement of antioxidant activity in human fluids. J Clin Pathol. 2001;54(5):356-61. https://doi.org/10.1136/ jcp.54.5.356

PMid: 11328833

28. BonserAM, Garcia-WebbP, HarrisonLC.C-peptidemeasurement: Methods and clinical utility. Crit Rev Clin Lab Sci. 1984;19(4):297352. https://doi.org/10.3109/10408368409165766 PMid:6373142

29. Li X, Zhou ZG, Qi HY, Chen XY, Huang G. Replacement of insulin by fasting $\mathrm{C}$-peptide in modified homeostasis model assessment to evaluate insulin resistance and islet beta cell function. Zhong Nan Da Xue Xue Bao Yi Xue Ban. 2004;29(4):419-23.

PMid:16134594

30. Boehm U, Klamp T, Groot M, Howard J. Cellular responses to interferon-gamma. Annu Rev Immunol. 1997;15(1):749-95. https://doi.org/10.1146/annurev.immunol.15.1.749 PMid:9143706

31. Fouad S, El Shebini SM, Abdel-Moaty M, Ahmed $\mathrm{NH}$ Hussein AM, Essa HA, et al. Nutritional supplement prepared from whole meal wheat flour, soya bean flour, flaxseed and anise seeds for alleviating the menopausal symptoms. J Biol Sci. 2018;18(7):381-8. https://doi.org/10.3923/jbs.2018.381.388

32. Wensveen FM, Jelenčić $V$, Valentić $S$, Šestan M, Wensveen TT, Theurich S, et al. NK cells link obesity-induced adipose stress to inflammation and insulin resistance. Nat Immunol. 2015;16(4):376-85. https://doi.org/10.1038/ni.3120 PMid:25729921

33. Jelodar G, Mohammadi M, Akbari A, Nazifi S. Cyclohexane extract of walnut leaves improves indices of oxidative stress, total homocysteine and lipids profiles in streptozotocin-induced diabetic rats. Physiol Rep. 2020;8(1):e14348. https://doi. org/10.14814/phy2.14348

PMid:31960621

34. Murphy MM, Douglass JS, Birkett A. Resistant starch intakes in the United States. J Am Diet Assoc. 2008;108(1):67-78. https:// doi.org/10.1016/j.jada.2007.10.012

35. Jin Y, Li P, Wang F. $\beta$-glucans as potential immunoadjuvants: A review on the adjuvanticity, structure-activity relationship and receptor recognition properties. Vaccine. 2018;36(35):5235-44. https://doi.org/10.1016/j.vaccine.2018.07.038 PMid:30049632

36. Pan P, Huang YW, Oshima K, Yearsley M, Zhang J, Arnold M, et al. The immunomodulatory potential of natural compounds in tumor-bearing mice and humans. Crit Rev Food Sci Nutr. 2019;59(6):992-1007. https://doi.org/10.1080/10408398.2018.1 537237

PMid:30795687

37. Vetvicka V, Vannucci L, Sima P. $\beta$-glucan as a new tool in vaccine development. Scand J Immunol. 2020;91(2):e12833. https://doi.org/10.1111/sji.12833

PMid:31544248

38. de Graaff P, Govers C, Wichers HJ, Debets R. Consumption of $\beta$-glucans to spice up $T$ cell treatment of tumors: A review. Expert Opin Biol Ther. 2018;18(10):1023-40. https://doi.org/10. 1080/14712598.2018.1523392

PMid:30221551

39. Aoe S, Ichinose Y, Kohyama N, Komae K, Takahashi A, Abe D, 
et al. Effects of high $\beta$-glucan barley on visceral fat obesity in Japanese individuals: A randomized, double-blind study. Nutrition. 2017;42:1-6. https://doi.org/10.1016/j.nut.2017.05.002 PMid:28870472

40. Redan BW, Buhman KK, Novotny JA, Ferruzzi MG. Altered transport and metabolism of phenolic compounds in obesity and diabetes: Implications for functional food development and assessment. Adv Nutr. 2016;7(6):1090-104. https://doi. org/10.3945/an.116.013029

PMid:28140326

41. Vernarelli J, Lambert J. Flavonoid intake is inversely associated with obesity and C-reactive protein, a marker for inflammation, in US adults. Nutr Diabetes. 2017;7(5):e276. https://doi. org/10.1038/nutd.2017.22 PMid:28504712

42. Shahidi F, Ambigaipalan P. Phenolics and polyphenolics in foods, beverages and spices: Antioxidant activity and health effects-a review. J Funct Foods. 2015;18:820-97. https://doi. org/10.1016/j.jff.2015.06.018

43. Tzounis X, Rodriguez-Mateos A, Vulevic J, Gibson GR, KwikUribe C, Spencer JP. Prebiotic evaluation of cocoa-derived flavanols in healthy humans by using a randomized, controlled, double-blind, crossover intervention study. Am J Clin Nutr. 2011;93(1):62-72. https://doi.org/10.3945/ajcn.110.000075 PMid:21068351

44. Schroder K, Hertzog PJ, Ravasi T, Hume DA. Interferon- $\gamma$ : An overview of signals, mechanisms and functions. J Leukoc Biol. 2004;75(2):163-89. https://doi.org/10.1189/jlb.0603252 PMid:14525967

45. Sheridan PA, Paich HA, Handy J, Karlsson EA, Hudgens MG, Sammon AB, et al. Obesity is associated with impaired immune response to influenza vaccination in humans. Int J Obes (Lond). 2012;36(8):1072-7. https://doi.org/10.1038/ijo.2011.208 PMid:22024641

46. Simonnet A, Chetboun M, Poissy J, Raverdy V, Noulette J, Duhamel A, et al. High prevalence of obesity in severe acute respiratory syndrome Coronavirus-2 (SARS-CoV-2) requiring invasive mechanical ventilation. Obesity (Silver Spring).
2020;28(7):1195-9. https://doi.org/10.1002/oby.22831 PMid:32271993

47. Fung TS, Liu DX. Human Coronavirus: Host-pathogen interaction. Annu Rev Microbiol. 2019;73:529-57. https://doi. org/10.1146/annurev-micro-020518-115759

PMid:31226023

48. Ziegler CG, Allon SJ, Nyquist SK, Mbano IM, Miao VN Tzouanas CN, et al. SARS-CoV-2 receptor ACE2 is an interferonstimulated gene in human airway epithelial cells and is detected in specific cell subsets across tissues. Cell. 2020;181:1016-35. e19. https://doi.org/10.3410/f.737831436.793574366 PMid:32413319

49. Imai Y, Kuba K, Rao S, Huan Y, Guo F, Guan B, et al. Angiotensinconverting enzyme 2 protects from severe acute lung failure. Nature. 2005;436(7047):112-6. https://doi.org/10.1038/ nature 03712

PMid: 16001071

50. Moustaka K, Maleskou E, Lambrianidou A, Papadopoulos S, Lekka ME, Trangas $\mathrm{T}$, et al. Docosahexaenoic acid inhibits proliferation of EoL-1 leukemia cells and induces cell cycle arrest and cell differentiation. Nutrients. 2019;11(3):574. https:// doi.org/10.3390/nu11030574

PMid:30866528

51. Fan P, Li L, Rezaei A, Eslamfam S, Che D, Ma X. Metabolites of dietary protein and peptides by intestinal microbes and their impacts on gut. Curr Protein Pept Sci. 2015;16(7):646-54. https://doi.org/10.2174/1389203716666150630133657 PMid:26122784

52. Hasan R, Rink L, Haase H. Chelation of free $\mathrm{Zn2+}$ impairs chemotaxis, phagocytosis, oxidative burst, degranulation, and cytokine production by neutrophil granulocytes. Biol Trace Elem Res. 2016;171(1):79-88. https://doi.org/10.1007/ s12011-015-0515-0 PMid:26400651

53. Carr AC, Maggini S. Vitamin $C$ and immune function. Nutrients. 2017;9(11):1211.

PMid:29099763 